\title{
ULAMA, MASJID DAN RUANG DEMOKRASI Pergumulan Elit Agama Menjelang Pilkada Serentak Tahun 2018 di Kalimantan Barat
}

\author{
Abdul Mukti \\ IAIN Pontianak \\ Email : mutirouf@yahoo.com
}

\begin{abstract}
Abstrak
Ulama sebagai pialang budaya (cultural broker) memiliki fungsi politik dalam ruang demokrasi. Kajian ini berupaya mengulas fungsional ulama dan diskursus yang berkembang, idealisasi figur pemimpin serta produksi narasi preferensi politik yang dsuplai untuk masyarakat pada kontestasi politik di ruang demokrasi di Kalimantan Barat. Kajian ini menggunakan metode kualitatif dan kerangka berfikir sosial-politik, sehingga dapat tergambarkan alur pemikiran (route map of thingking) para ulama Kalimantan Barat dan posisinya di ruang demokrasi. Ulama Kalimantan Barat telah menyiapkan propaganda doktriner berupa nalar kompetisi bagi calon kontestan muslim di ruang demokrasi, berikutnya juga terdapat naratical prferference yang disampaikan lewat masjid bagi para calon pemilih, hanya saja belum dilengkapi dengan tujuan yang jelas (immesurable purpose) sehingga sulit untuk mencari figur pemimpin yang diinginkan. Walau demikian, Ulama Kalimantan Barat dalam ruang demokrasi dan kebangsaan berada dalam posisi moderat, sehingga juga ramah dengan ragam perbedaan baik dari kontestan maupun pada keragaman preferensi pemilih.
\end{abstract}

Kata Kunci : Ulama; Masjid; Demokrasi

\section{A. Konteks Kajian}

Ulama bagi umat Islam Indonesia memiliki peran penting, tidak hanya pada sektor keagamaan namun juga telah mengambil kendali di berbagai lini kehidupan sosial lainnya, seperti dalam bidang budaya dan politik. Oleh karena itu, fungsi ulama di Indonesia disebut dengan pialang budaya (cultural broker) ${ }^{1}$.

Sisi normativitas Islam ikut menyokong hadirnya ulama di kawasan politik. Disitulah peran ulama mengambil posisi ligitimator teks keagamaan sekaligus pada saat yang sama para ulama juga berhadap-hadapan dengan dinamika umat Islam yang kompleks dan kontekstual. Walau demikian, kehadiran ulama di lingkungan politik memunculkan varian persepsi, satu sisi ada kelompok yang menerima,di sisi lain terdapat kelompok yang menolaknya dengan harapan agar para ulama cukup berada di kawasan yang netral.

Fungsi sentral yang melekat pada ulama terhadap kehidupan umat Islam adalah unsur yang paling riil untuk diterima secara suka atau tidak oleh setiap

\footnotetext{
${ }^{1}$ Geertz berpandangan bahwa peran kiai berubah dari semata-mata sebagai perantara dalam mengkomunikasikan dan menyesuaikan doktrin-doktrin Islam ke dalam praktik dan keyakinan lokal masyarakat Jawa, kepada fungsi yang membuat mereka terlibat sebagai perantara isu politik nasionalisme bagi penduduk desa. Lihat Clifford Geertz, The Religion of Java (Chicago and London: The University of Chicago Press, 1960), dan Clifford Geertz, "The Javanese Kijaji: the Changing Role of a Cultural Broker," dalam Comparative Studies in Society and History, Vol. 2 No. 2 (1960), 228-249.
} 
individu mengenai kehadiran ulama di lingkungan politik, baik eksplisit maupun secara implisit. Sisi lain yang tidak dapat dipisahkan dari fungsi sentral tersebut adalah masjid. Disini masjid tidak sekedar menjadi simbol keagamaan tetapi juga menjadi titik jumpa budaya, pergesekan bahkan pembentukan arah budaya dan citacita umat ke depan, termasuk intensitas perhatian ulama dan umat terhadap kontestasi politik yang mengemuka.

Satu fakta mengenai kehadiran ulama di lingkungan politik serta pergumulannya dengan menggunakan simbol-simbol keagamaan seperti masjid dapat dilihat pada kontestasi Gubernur Jakarta pada tahun 2016. Disitulah sejumlah ulama terlibat secara langsung, seperti Habieb Riziek Shihab, Bahctiar Nashir dan sejumlah tokoh nasional lainnya berhasil menghimpun suatu pergerakan politik yang cukup besar dengan suatu kemasan aksi damai 212 yang menggugat calon gubernur petahana Basuki Tjahya Purnama untuk diproses secara hukum dengan tuduhan sebagai penista agama ${ }^{2}$.

Fakta tersebut satu sisi adalah fakta kegerahan keagamaan, tetapi di sisi yang lain adalah bagian dari fenomena politik. Konteks gelaran pilkada saat itu yang mempertemukan calon muslim yang berhadapan dengan non muslim yang kemudian berujung dengan suatu statement politik, berupa suara ajakan untuk memilih muslim dan tidak boleh memilih penista agama adalah sisi politik yang tidak dapat diabaikan. Sebagai puncaknya, pasangan Anies-Sandi keluar sebagai pemenang pilkada dan Ahok meringkuk di penjara ${ }^{3}$.

Keberhasilan kehadiran ulama pada kontestasi Pilkada Jakarta menjadi warna baru suksesi politik di Indonesia, yang kemungkinan juga akan diadaptasi oleh sejumlah suksesi politik lainnya di berbagai daerah di Indonesia, termasuk pada pilkada 2018 Kalimantan Barat. Namun demikian pola adaptasi tersebut akan banyak menguak fakta baru yang barangkali bisa jadi berbeda dengan apa yang terjadi di Jakarta. Hal tersebut sangat terkait dengan sejumlah masalah fenomena problematis tentang artikulasi politik umat Islam di Kalimantan Barat di antaranya berupa diskoneksitas partisipasi politik antara jumlah penduduk dan afiliasi politiknya.

Jumlah penduduk muslim yang lebih besar sebanyak 3.196 .109 (59,6 \%) tidak berbanding lurus dengan capaiannya dengan terpilihnya Cornelis menjadi gubernur selama dua periode sejak pilgub pada tahun 2009 dan pilgub pada tahun 2013 yang notabenenya beragama Katolik dengan sebaran penduduk sebesar 1.196.997 (22,3\%). Untuk menggambarkan jumlah penduduk menurut agama dapat dilihat dalam tabel berikut ${ }^{4}$ :

2 IPAC Report, After Ahok: The Islamist Agenda in Indonesia (Institute For Policy Analysis of Conflict IPAC, 6 April 2018), h. 1

${ }^{3}$ ibid, h. 3

${ }^{4}$ http://dukcapil.kalbarprov.go.id/statistik/agama 


\begin{tabular}{lrrr}
\hline \multicolumn{1}{c}{ AGAMA } & LAKI LAKI & PEREMPUAN & \multicolumn{1}{c}{ JUMLAH } \\
\hline Islam & 1.638 .131 & 1.557 .978 & 3.196 .109 \\
Kristen & 317.842 & 295.523 & 613.365 \\
Katolik & 620.563 & 576.434 & 1.196 .997 \\
Hindu & 1.733 & 1.493 & 3.226 \\
Budha & 176.387 & 163.217 & 339.604 \\
Khonghucu & 6.459 & 5.739 & 12.198 \\
Aliran & & 1.650 & 3.465 \\
Kepercayaan & 1.815 & & \\
& $\mathbf{2 . 7 6 2 . 9 3 0}$ & $\mathbf{2 . 6 0 2 . 0 3 4}$ & $\mathbf{5 . 3 6 4 . 9 6 4}$ \\
\hline
\end{tabular}

Dengan fakta kuantitas-kualitas yang tergambar dalam hasil pemilihan gubernur dan wakil gubernur pada tahun 2009 dan 2013, telah menunjukkan-baik sebagai fakta maupun teoritis - bahwa tidak ditemukan terjadi linieritas antara identitas keagamaan seseorang atau kelompok dengan afiliasi politiknya. Dengan fakta itu pula, dapat dikatakan bahwa penerjemahan ideal-normatif oleh kalangan elit agama tertentu tentang hubungan Islam dan politik seringkali menemukan kegagalan dalam ranah yang lebih praktis-sosiologis. Gagasan tentang "ukhuwah Islamiyah" - apalagi dalam ranah politik praktis - selalu ditemukan faktor-faktor non agama yang terlibat secara aktif dalam menentukan kemepemipinan politik suatu daerah. Dua kali pemilihan gubernur-wakil gubernur di Kalimantan Barat adalah kasus yang dapat dijadikan contoh untuk membuktikan tesis di atas. Fenomena ini sering memunculkan pertanyaan teoritik yaitu apakah pandangan tentang teologi politik seeseorang atau kelompok dapat diterjemahkan secara rigid dan mudah - sebagaimana umumnya pandangan fundamentalis - ke dalam ruangruang politik praktis yang memiliki variabel yang lebih kompleks?

Dengan gambaran dan ukuran sepuluh tahun terakhir tersebut, diskursus tentang bagaimana gagasan persatuan umat Islam di Kalimantan Barat diduga akan kembali menguat dalam mendiskusikan tentang aspirasi umat Islam dalam konteks pemilihan gubernur-wakil gubernur yang akan melibatkan elit agama (ulama) dan berbagai aktivitas beberapa masjid di Kalimantan Barat. Sedangkan fakta keberhasilan di Jakarta akan menjadi prototipe keberhasilan pergumulan elit agama dalam menentukan preferensi pilihan politik umat Islam di Kalimantan Barat.

Berdasar konteks di atas, maka kajian ini setidaknya akan mengungkap tiga hal penting diantaranya, diskursus keagamaan yang dugunakan para elit, idealisasi figur pemimipin dan yang terakhir tindakan dan konsepsi para elit dalam mengarahkan preferensi pilihan politik masyarakat muslim Kalimantan Barat.

\section{B. Islam dan Politik}

Islam dan kekuasaan adalah dua hal yang tidak dapat dipisahkan. Normativitas dan historisitas relasi keduanya telah menjadi bagian dari kekayaan peradaban dunia. Didalamnya termuat berbagai macam khazanah, mulai dari pemikiran, gerakan dan monumen fisik, baik sebagai sebuah peninggalan masa lampau, momentum yang sedang berlangsung maupun proyek espektasi dan masa depan. Dari situ kemudian melahirkan berbagai macam respon, dari sekedar mengagumi, mempelajari bahkan ada yang mencoba untuk mengkonfrontasi sebagai kompetitor dari sejumlah peradaban besar lainnya. 
Apapun bentuk alasan dalam menyikapi Islam sebagai agama dan politik tidak menggeser posisi Islam sebagai bagian peradaban besar dunia. Hal tersebut berkaitan erat dengan keajegan (baca:kokoh dan utuh) Islam yang memuat dua keimanan pokok, yaitu iman terhadap Al-Qur'an sebagai friman Allah dan iman kepada Nabi Muhammad sebagai role model manusia sempurna (insan kamil) dan espektasi setiap muslim. ${ }^{5}$

Relasi fundamen keimanan yang pertama dengan yang kedua mengandaikan adanya acuan sumber petunjuk dan implementasi. Dalam hal ini AlQuran sebagai sumber pentunjuk sedangkan Muhammad adalah wujud nyata sebagai pesan tersirat dari urutan ayat dan surat di dalam al-Quran. Maka tubuh Muhammad dan kehidupannya dapat dimaknai sebagai al-Quran yang menyejarah, sedangkan al-Quran dalam bentuknya sebagai wahyu adalah pengikat dan tempat berpulang dari segala kerumitan yang perlu diselesaikan. Konsepsi keterkaitan dua fundamen itulah yang kemudian menempatkan Islam sebagai agama paripurna dengan jangkauannya yang meliputi segala aspek kehidupan, termasuk di dalamnya politik itu sendiri.

Memasukkan politik sebagai bagian dari Islam menuai diskursus baru, sebagian disetujui dan sebagian yang lain ada yang mencoba untuk memilahnya. Namun keterhubungan Islam dan politik tidak dapat diabaikan. Hal yang paling penting sebenarnya bukan pada perdebatan integralitas Islam dan politik atau disintegralitasnya, tapi yang paling penting adalah melihat bagaimana realitas itu telah membentuk diskursus baru. Pada awalnya Islam memang hanya diyakini sebagai sistem keyakinan dan budaya. Namun dalam beberapa dekade terakhir, dunia mengalami krisis dari berbagai sektor, seperti krisi dalam sektor ekonomi, politik dan budaya. Sejumlah krisis tersebut meminta suatu pendekatan baru yang betul-betul memadai untuk menjawab sejumlah krisis yang terbilang sangat struktural. Disinilah Islam mengambil posisi, sehingga Islam tidak hanya sekedar sistem kepercayaan tetapi juga telah memasukkan politik sebagai bidang garapan realitas yang perlu juga dituntaskan. ${ }^{6}$

Barangkali gejala di atas belum terlalu gamblang untuk menjelaskan bagaimana sebenarnya relasi Islam dan politik itu saling berkaitan. Namun jika melihat pada kebutuhan umat muslim sebagai bagian dari masyarakat dunia, tentu krisis ekonomi, sosial dan budaya adalah realitas yang tidak dapat dipisahkan dari kehidupannya. Untuk itu Islam tidak bisa menempatkan dirinya terpisah dari kehidupan umat muslim itu sendiri dengan hanya mengklaim sebagai sistem kepercayaan. Integralitas Islam dan politik sama sepadannya dengan inherenitas kehidupan muslim dengan transaksi ekonomi dan kebijakan politik serta kehidupan sosial lainnya, sehingga dengan sendirinya harus diakui bahwa Islam dan politik adalah benar-benar dua hal yang tidak dapat dipisahkan.

Sampai disini keraguan itu bisa jadi telah bergeser menjadi suatu keyakinan bahwa integralitas Islam dan politk adalah kenyataan yang tidak dapat diabaikan. Namun hal tersebut juga tidak berhenti sampai disitu, tapi terus beranjak pada pertanyaan berikutnya mengenai bentuk keterhubungan keduanya. Apakah integralitas tersebut sama dengan menyatakan bahwa Islam itu adalah agama dan

\footnotetext{
5 John M. Owen, Confronting Political Islam, (New Jersey: Princeton University Press, 2015), h. 20

${ }^{6}$ Bassam Tibi, Islam Between Culture and Politics, (New York: Palgrave Macmilan, 2001), h. Ix-X
} 
pemerintahan (addin wa daulah) atau hanya sekedar keterhubungan secara esensial. Islam sebagai addin wa daulah menjadi suatu keterhubungan yang sanga simbolikformalistik. Sementara di sisi lain ada yang memaknai bahwa Islam dan politik itu keterhubungan pada persoalan sentral moral. Disini Islam berperan sebagai sumber dan pusat moralitas dalam menata masyarakat. Pada pilihan kedua inilah yang telah dicontohkan oleh Nabi Muhammad dalam Piagam Madinah yang dapat dibilang sebagai nota politik dan dasar kehidupan sosial masyarakat Madinah sebagai suatu negara saat itu. Disitulah Madinah menjadi negara tanpa sengaja menyebut negara Islam, namun yang diutamakan adalah tujuan bernegara dalam membangun perdamaian dengan menaungi seluruh masyarakat yang ada di dalamnya. Inilah bentuk integralitas Islam dan politik, esensialitas Islam sebagai sumber moral diutamakan daripada unsur simbolik-formalistiknya. Bentuk inilah sebenarnya yang semestinya menjadi karakteristik relasi Islam dan politik bahkan juga menjadi karakter dari konsep Islam sebagai agama dan kekuasaan (baca: negara) ${ }^{7}$.

Sejatinya perbandingan antara perdebatan penyatuan Islam dan politik dan pemisahannya lebih dominan pada persoalan konstruk penyatuannya. Perdebatan pemisahan Islam dan politik dapat dibilang tidak sesemarak yang terjadi di Barat. Karena dari sejak awal universalitas Islam tidak mengalami kendala terhadap berbagai aspek, sehingga jika belakangan muncul wacana integralitas antara Islam dan politik juga tidak memicu lonjakan perdebatan yang berarti. Berbeda dengan Barat yang sejak awal memiliki problem keutuhan yang lemah khususnya antara dominasi agama (gereja) dan kekuasaan. kelemahan itu terlihat pada abad pertengahan yang menampilkan persetegangan agama dan kekuatan ilmu pengetahuan. Pengetahuan pada saat itu diklaim menjadi unsur penyelematan terhadap Barat sehingga muncullah era Renaissance atau pencerahan yang pada intinya rasionalitas telah menggeser pengaruh agama. Mulai saat itulah sekularisasi (pemisahan) agama dari hiruk pikuk dunia makin kuat hingga merambah pada kehidupan politik. Agama hanya menjadi cagar kehidupan yang sangat personal, sedangkan ruang sosial dan politik menjadi tugas ilmu pengetahuan untuk mengaturnya. ${ }^{8}$

Jadi persoalan penolakan integralitas agama dan politik yang terjadi di tengah-tengan muslim secara tidak langsung banyak dipengaruhi oleh situasi yang terjadi di Barat. Sebagaimana pada beberapa dimensi kehidupan yang lain, umat muslim juga banyak berkiblat ke Barat. Secara implisit apa yang terjadi di Turki pada masa Mustafa Kemal Pasha Ataturk yang menerapkan ide sekularisme secara berlebihan sebagai dampak nyata dari pengaruh Barat saat itu. Pada akhirnya egoisme itu juga tidak dapat dijadikan representasi keberhasilan dari pemisahan agama dan politik.

Barangkali munculnya ide negara Islam adalah salah satu bagian dari mengkristalnya Islamisme yang meghadirkan keterhubungan formal dan politik secara langsung. Sebagaimana juga kehadiran sekularisme yang muncul akibat dari pengaruh Barat, sehingga pada saat yang sama dapat juga disebut dengan westernisme. Islamisme memandang bahwa kegagalan politik sebagai sistem yang mengatur negara akibat dari hilangnya kontrol agama. Sementara sekularisasi

${ }^{7}$ Nazih N Ayubi, Political Islam: Relegion and Politic in The Arab World (New York :Taylor and E Library 1991), h. 10

${ }^{8}$ Peter Mandaville, Global Politic Islam, (New York : Taylor and E-Library, 2007), h. 9- 
memandang bahwa persoalan keduniaan adalah persoalan saat ini, disini dan bukan untuk yang diluar sana atau setelah ini. Maka segala apapun yang menghalangi pandangan obyektif mengenai dunia harus disisihkan, termasuk mitos dan segala simbol kesucian. ${ }^{9}$

Sentimen dua kubu ekstrem tersebut berlangsung cukup lama dan serius. Islam dalam hal ini mengambil jalan tengah, pada satu sisi Islam tidak mengajukan secara simbolik-formalistik namun lebih mengedepankan aspek esensial. Secara sederhana, relasi Islam dan politik tidak hanya mengandalkan teks dogmatis yang sangat sakral, akan tetapi juga selalu mengaitkan dengan kehadiran Muhammad sebagai perwujudan historis dari teks dogmatis yang sakral.

Maka dengan demikian Islam dan politik tidak dapat dipisahkankan, tapi juga tidak dapat dituduh sebagai penghalang pandangan obyektifitas keduniaan dan kekinian, mengingat Muhammad adalah bagian dari manusia yang juga telah menyejarah sebagai bagian dari dunia dan kekinian. Keterpaduan Islam dan politik pada sisi yang lain juga tidak mengharuskan muncul negara Islam, karena keterpaduannya terletak pada tujuan bukan pada simbolnya. Dengan demikian, segala tujuan politik seperti keadilan, kesejahteraan dan keharmonisan harus selalu terukur (profan-historis) untuk kepentingan kehidupan masyarakat dunia bukan semata-mata kepentingan pengabdian kepada Tuhan (saklral-mitis).

\section{Ulama dalam Politik}

Ulama adalah term yang tidak asing bagi umat Islam. Ulama adalah sosok yang memiliki pengetahuan agama dan posisi yang cukup prestesius. ${ }^{10}$ Kehadirannya telah banyak memberikan pengaruh besar terhadap umat Islam secara umum. Berbagai hasil karya para ulama dari berbagai bidang keilmuan telah menempatkan posisi ulama sebagai elemen penting dalam kehidupan umat Islam, baik dalam tata cara beribadah maupun dalam kehidupan sosial. Dalam pemahaman awam, terma ulama, umara dan aghniya adalah tiga term penting dalam kehidupan, termasuk dalam konteks politik. Relasi ketiganya diumpakan sebagai sebuah relasional mutualisme, khususnya relasi antara ulama dan umara $^{11}$.

Relasi mutualisme tersebut cukup kental, ulama bekerja menyiapkan legitimasi keagamaan terhadap klaim yang dikeluarkan oleh pemerintah. Begitu juga kemudian pemerintah memberikan perlindungan dan apresiasi berupa dorongan finansial dan kekuatan ideologis kepada para ulama. Begitulah sejarah mencatatnya, termasuk yang juga terhadi pada dinasti Safawi. ${ }^{12}$

Kehadiran para ulama di ruang politik tidak hanya sekedar mendukung suatu rezim tertentu, tapi mungkin bisa dikategorikan sebagai instrumen vital politik. Hal tersebut sangat terlihat pada setiap rezim yang selalu bergandengan dengan ulama, sehingga pada sisi yang lain terjadi counter attack dari lawan pemerintah dengan sama-sama menghadirkan ulama. Sepeti halnya pada saat dinasti Safawi tumbang, maka ulama Syi'ah juga ikut dimarginalisasi yang

9 Harvey Cox, The Secular City; Secularization and Urbanization in Theological Perspective, (New York: The Macmillan Company, 1965), 2

${ }^{10}$ Stephen Humpreys, Islamic History: A Frame Work for Inquiry (London: I.B. Thauris, 1999), h. 187

11 Sena Karisipahi, "Comparing Islam Resurgance Movement Turkey and Iran " The Middle Est Journal, Vol. 63, No. 1. 2009.

12 Nikki R. Kiddie, "The Roots of The Ulama's Power in Modern Iran" Studia Islamica, No. 29, 1969. 
kemudian diikuti dengan hadirnya dominasi ulama Sunni yang pada saat itu menyokong Nadir Syah. ${ }^{13}$

Iran dalam hal ini memang cukup representatif untuk dijadikan obyek kajian mengenai relasi ulama dan politik. Karena revolusi Iran itu sendiri adalah bagian penting dari peran ulama dalam dunia politik. Tahun 1989 Ayatullah Khomeini pernah menyatakan bahwa kita semua berhutang banyak kepada para agamawan (baca: ulama). Karena sejarah telah banyak memperlihatkan bahwa sebagian besar gerakan revolusioner banyak dimotori oleh para agamawan, hingga kemudian mereka jugalah yang menjadi orang-orang pertama yang syahid. Mereka para agamawan adalah orang yang selalu membela orang-orang yang tertindas dalam melawan para penyembah uang. ${ }^{14}$

Dalam tradisi umat Islam di Indonesia, faktualitas kesakralan yang dibawa oleh ulama untuk tujuan yang bersifat politis biasa dikenal dengan kharisma. Kharisma dalam terminologi ilmu sosial berkaitan dengan otoritas. Seseorang yang memilikinya akan mampu mempengaruhi, memerintah bahkan mendominasi tanpa adanya perlawanan. Disinilah ulama dalam tradisi Islam di Indonesia sangat deterministik terhadap berbagai perubahan sosial, termasuk dalam politik ${ }^{15}$. Sehingga dengan demikian posisi ulama di lingkungan politik sangat vital.

Secara historis dalam konteks perjuangan melawan penjajah, kata ulama dalam tradisi Indonesia juga dikenal dengan beberapa istilah, diantaranya yang sangat populer adalah sebutan Kiyai. Sebutan kiyai memiliki arti yang sangat kompleks diantaranya, pemimpin pesantren, pemimpin agama sekaligus juga sosok yang secara konsisten melakukan perlawanan terhadap dominasi penjajah. ${ }^{16}$

Posisi vital ulama dalam sejarah perjuangan melawan penjajah dan segala perubahan sosial di Indonesia memang sangat terasa. Bahkan suatu kebangkitan bangsa sangat ditentukan oleh kebangkitan ulamanya, oleh karena itu kemudian di Indonesia kita mengenal adanya Nahdlatul Ulama (NU). Selain dari itu pada tanggal 21 Oktober $1945 \mathrm{KH}$. Abdul Wahab Hasbullah menetapkan suatu keputusan yang diberi nama "Resolusi Jihad Fi Sabilillah". Resolusi tersebut pada intinya adalah ajakan menolak dan melawan penjajahan. ${ }^{17}$

Melihat sejumlah penjelasan di atas, baik yang terjadi di Iran maupun yang terjadi di Indonesia keduanya sama-sama menunjukkan posisi vital ulama di tengah-tengah perubahan politik. Sehingga dengan demikian Khomeini menyatakan bahwa masyarakat banyak berhutang kepada para ulama yang dia sebut dengan agamawan. Karena mereka tidak hanya mendorong tetapi juga ikut aktif berjuang hingga kemudian ada yang harus mati syahid (mati suci) untuk sebuah kepentingan yang suci. Kegigihan perlawanan secara langusng untuk suatu perubahan politik dan sosial dalam konteks Indonesia ada pada Resolusi Jihad yang dikumandangkan oleh KH. Abdul Wahab Hasbullah.

\footnotetext{
${ }^{13}$ Azar Tabari, “ The Role of The Clergy in Modern Iranian Politics, dalam Robert D. Lee "Religion and Politic in Iran, (New York: Westview Press, 2014), h. 48

${ }^{14}$ Ervan Abrahamian, Khomeinism Essays on The Islamic Republic, (Berkeley: Universitas of California Press, 1993), h. 88

15 Achmad Zainal Arifin, Charisma and Rasionalisation in Modernising Pesantren: Changing Values in Traditional Islamic Education in Java (Sydney : The University of Western Sydney, 2013), h. 6

${ }^{16}$ B.J. Bolland, The Struggle of Islam in Modern Indonesia (London: Springer, 1982), h.7

17 "Resolusi Jihad NU Dan Perang Empat Hari Di Surabaya | NU Online," accessed January 10, 2017, http://www.nu.or.id/post/read/72250/resolusi-jihad-nu-dan-perang-empat-hari-disurabaya-
} 
Posisi vital tersebut bangkit dari adanya otoritas yang melekat pada diri seorang ulama karena kekhususan yang membedakan dirinya dari orang banyak. Seperti kepribadian yang suci, pemahman agama yang luas, penghambaan yang tulus hingga kemudian menjadikan dirinya memiliki kualitas yang khusus. Berikutnya segala kekhasan tersebut kemudian dikenal dengan otoritas kharismatik. ${ }^{18}$ Otoritas kharismatik ini hanya dapat berlaku di lingkungan yang masih sangat tradisional. Artinya pemberian legitimasi atas dasar otoritas kharismatik tidak selamanya berjalan cukup baik, terlebih ketika kondisi masyarakat begitu sangat majemuk. Disinilah kemudian otoritas itu sendiri memerlukan kekuatan (power). ${ }^{19}$

Kebutuhan otoritas kharismatik terhadap sebuah kekuatan, secara implisit akan mengarahkan para ulama pada suatu kebutuhan terhadap kehadiran pemerintah. Pada sisi yang lain, pemerintah juga memerlukan dukungan para ulama untuk mejalankan kepentingannya, karena ulama tetap memiliki pengaruh yang cukup signifikan. Disinilah dua kepentingan tersebut bertemu dan sekaligus mengawali hadirnya Majlis Ulama Indonesia (MUI) sebagai titik jumpa kelembagaan yang menjembatani kepentingan pemerintah dan kepentingan masyarakat muslim. Dalam wadah MUI itulah seluruh kelompok Islam bernaung, mulai dari kelompok tradisional NU, kelompok modern seperti Muhammadiyah dan kelolompok Islam lainnya. ${ }^{20}$

Satu hal lagi yang barangkali sangat aktual terkait dengan relasi ulama dan politik di Indonesia. Akhir tahun 2016 terjadi peristiwa yang cukup spektakuler yang kemudian dikenal dengan aksi damai 212. Pada aksi tersebut terlibat dua tokoh nasional sebut saja seperti Habib Rizieq Shihab dan Bahctiar Nashir. Kedua tokoh tersebut dapat dikatakan sebagai ulama. Mengingat keduanya adalah sosok yang cukup aktif bergerak di dunia dakwah, serta mempunyai kharisma yang cukup mumpuni untuk mendorong publik melakukan suatu pergerakan. Keduanya berhasil menggelar aksi demonstrasi yang sangat besar dengan suatu tuduhan adanya penistaan agama yang telah dilakukan oleh gubernur Jakarta saat itu Basuki Tjahya Purnama atau Ahok agar diproses secara hukum. ${ }^{21}$

Gerakan tersebut begitu sangat berdekatan dengan kepentingan politik. Karena pada saat yang sama gelombang besar demonstrasi tersebut bertepatan dengan pemilihan gubernur Jakarta. Satu sisi demonstrasi tersebut bisa jadi berangkat dari kesadaran keagamaan, namun di sisi yang lain adanya gelombang politik juga tidak dapat dipinggirkan. Kekentalan nuansa politik tersebut selain tuntutan hukum yang ditujukan pada Ahok karena pidatonya tentang surat alMaidah ayai 51 juga terdapat ajakan untuk umat Islam agar memilih calon pemimpin muslim. Hasilnya tanggal 19 April 2017 Anies Baswedan memenangkan pemilihan gubernur Jakarta dengan 58 persen suara sedangkan Ahok mengantongi

\footnotetext{
${ }^{18}$ Max Weber, Theory of Social and Economic Organization (Glancoe-III: The Free Press, 1957),h. 329

${ }^{19}$ Elmer S. Miller and Charles A. Weitz, Introduction to Anthropology (Eaglewood Cliffs: Prentice-Hall Inc, 1979), h. 530

${ }^{20}$ M. Atho Mudzhar, Fatwa of the Council of Indonesian Ulama: A Study of Islamic Legal Thought in Indonesia 1975-1988 (Jakarta: INIS, 1993), h. 47-48.

${ }^{21}$ IPAC Report, After Ahok: The Islamist Agenda in Indonesia (Institute For Policy Analysis of Conflict IPAC, 6 April 2018), h. 1
} 
sekitar 42 persen. Tepat pada tanggal 9 Mei 2017 dijatuhi hukuman 2 tahun penjara karena tuduhan kasus penistaan agama. ${ }^{22}$

Peristiwa Ahok seakan menjadi penanda yang cukup kentara adanya relasi ulama dan politik yang sangat kental. Bahkan peran ulama disitu sudah sangat modern, tidak hanya bermodalkan otoritas kharismatiknya akan tetapi sudah berbentuk gerakan-gerakan yang terorganisir. Dilaporkan terdapat beberapa kelompok aliran yang ikut andil dalam gerakan besar 212, diantaranya modernis salafi yang diprakarsai oleh Bachtiar Nasir dengan GNPF-MUI (Gerakan Nasional Pengawal Fatwa MUI). Kemudian ada FPI (Front Pembela Islam) yang dinahkodai oleh Habib Rizieq Shihab. Berikutnya ada pengaruh Hizbut Tahrir Indonesia (HTI), Forum Umat Islam dan Majlis Dzikir. Jika ditelusuri satu per satu dari setiap kelompok yang tergabung dalam gerakan 212 semuanya memiliki latar belakang keterkaitan erat dengan politik. ${ }^{23}$

Keberhasilan keikutsertaan ulama dalam peristiwa politik pada pemilihan gubernur di Jakarta diasumsikan juga akan terus berlanjut pada pemilihan umum presiden tahun 2019. Isu yang akan mengemuka adalah persoalan Islamisme, sebagaimana isu tersebut berhasil memenjarakan Ahok yang kebetulan Nasrani dan memenangkan Anies sebagai representasi pemimpin muslim. Selain dari isu, jejaring gerakan 212 dirasa cukup kuat karena telah melibatkan umat Islam dari seluruh Indonesia, sehingga dengan demikian akan sangat mudah diarahkan untuk menentukan arah dan kecenderungan politik yang akan datang. ${ }^{24}$

Jika dilihat lebih dekat, peristiwa 212 yang terbilang sebagai gerakan besar tidak sejalan dengan kelompok yang mendukungnya, dimana dalam hal ini komunitas atau organisasi mainstream umat Islam Indonesia seperti NU dan Muhammadiyah memilih absen di dalamnya. Sebaliknya, kelompok-kelompok kecil yang selama ini terabaikan tiba-tiba berhasil menguat bahkan kini mengambil peran yang cukup kuat dalam mengarahkan kecenderungan politik ke depan.

Fenomena yang terjadi di Indonesia sejalan dengan apa yang terjadi di Iran, dimana pergeseran pengaruh ulama dalam dunia politik itu sangat dinamis. Misalnya, dinamika di Iran adalah perebutan pengaruh ulama Sunni-Syiah, sementara di Indonesia bisa saja terjadi persaingan ulama salafi, modernis salafi, tradisional revivalis dan moderat. Maka relasi ulama dan politik itu adalah relasi otoritas kharismatik dan kekuasaan. Disitulah kemudian ada gerakan, ajakan dan legitimasi. Pada saat yang sama politik akan memberikan yang sepadan dengan memberikan timbal balik untuk mengavirmasi otoritas kharismatik ulama melalui kekuasaan.

\section{Masjid di Lingkungan Kekuasaan}

Masjid secara kasat mata adalah rumah ibadah yang tidak jauh berbeda dengan rumah ibadah agama lainnya. Disitulah tempat berkumpulnya umat untuk sebuah ritual yang sakral. Belakangan di Amerika muncul suatu inisiasi untuk mengamati masjid sebagai salah satu simbol Islam yang dalam dua dekade trakhir Islam dicitrakan dengan kelompok teroris. Pengamatan itu pada awalnya adalah bagian dari sentimen terhadap Islam, dimana masjid di Amerika tidak sekedar

\footnotetext{
${ }^{22}$ Ibid, h. 3

${ }^{23}$ Ibdi 3-4

${ }^{24}$ Ibid, h. 25
} 
sebagai tempat ibadah, tetapi lebih tepat disebut pusat komunitas muslim dimana seluruh persoalan seringkali harus dijawab di masjid. ${ }^{25}$

Untuk membaca masjid secara komprehensif harus melihat pada masjid di zaman Rasulullah. Pada saat itu masjid adalah tempat melaksanakan sholat jamaah. Selain itu di masjid itulah juga bertemu antara anshor dan muhajirin yang merepresentasikan antara penolong dan kelompok yang harus ditolong. Orang yang memberikan makanan dengan orang yang membutuhkan makanan. Di masjid itu pula dibuat dan diputuskan sejumlah aturan. Disitu juga tempat untuk memutuskan hukum, mempersiapkan tentara, tempat menerima utusan dari berbagai suku dan disitu juga sekolah pertama Islam bermula. ${ }^{26}$

Secara ringkas pada zaman nabi masjid itu tidak hanya berfungsi sebagai rumah ibadah akan tetapi juga rumah administrasi, pendidikan, militer dan pengadilan. Namun term masjid tetap tidak dapat dipisahkan dengan status dan maknanya sebagai rumah suci. ${ }^{27} \mathrm{Hal}$ yang menarik dari apa yang dilakukan Nabi terhadap keberadaan masjid, beliau juga menempatkan rumahnya tidak jauh dari masjid. Bahkan di halaman depan masjid beliau membangun pondok-pondok kecil untuk para istri beliau. ${ }^{28}$ Barangkali pesan yang ingin disampaikan oleh Nabi, bahwa masjid itu juga tidak hanya diperuntukkan untuk kebutuhan sosial, tapi juga sebagai tempat untuk menyelesaikan persoalan domestik.

Semasa Abu Bakar fungsi masjid masih tidak terlalu berbeda dengan masa Rasulullah. Pada masa Umar kemudian masjid memiliki fungsi yang dapat dibilang cukup baru dengan membuat teritori masjid. Disitulah kemudian diberlakukan kebijakan bagi non muslim yang berada di dalam garis teritori untuk membayar pajak $^{29}$. Disini masjid sudah memiliki fungsi sebagai sumber ekonomi.

Fungsi masjid di atas kemudian berlanjut hingga dinasti Abbasiyah. Terhitung saat itu Islam telah memiliki 7000 masjid di Basra dan 30.000 di kota Baghdad $^{30}$. Kondisi yang sama juga berkembang ke seluruh penjuru termasuk juga ketika Islam masuk ke Eropa. Secara umum seluruh masjid tersebut tetap mempertahankan fungsinya untuk memberikan layanan sosial, politik dan pendidikan. Perkembangan yang dirasa cukup berbeda pada masa Abbasiyah ini di lingkungan masjid terdapat pendidikan formal, dimana kurikulum dan kitab-kitab juga mulai disajikan secara klasikal oleh para ulama yang mengajar di sekitar masjid, yang kemudian disebut dengan madrasah. ${ }^{31}$

Keberadaan Islam dan ekspansinya memang selalu diikuti dengan bertambahnya masjid. Artinya, masjid itu selalu menjadi unsur penting dalam Islam dan kekuasaan dalam Islam. Dari pertumbuhan masjid itu juga Islam itu telah mengubah wajah dunia, mulai dari sistem pemerintahan dan kenegaraan, sosial, hukum, pemikiran dan seni. Semua perkembangan tersebut, mulai dari Timur

\footnotetext{
${ }^{25} \mathrm{https}$ ///surface.syr.edu/honors_capstone

${ }^{26}$ Karen Amstrong, Muhammad Prophet for Our Time (New York : Harper Collins, 2007), h. 107

${ }^{27}$ Francis E. Peters, Muhammed and the Origins of Islam (Albany, NY: State University of New

York Press, 1994), h. 194.

${ }^{28}$ Karen Amstrong, Muhammad Prophet for Our Time..h. 104

${ }^{29}$ Ibid, h. 43

${ }^{30}$ Mohamed Makki Sibai, Mosque Libraries (New York, NY: Mansell Publishing Limited, 1987), 8

${ }^{31}$ Ibdi, h. 31
} 
Tengah, Afrika, Eropa dan Asia Timur di bawah dominasi Islam di bawah dinasti Abbasiyah. ${ }^{32}$

Indonesia sebagai negara dengan penduduk muslim terbesar di dunia juga tidak asing dengan masjid. Pada tahun 1972 masjid memiliki organisasi khusus yang disebut dengan Dewan Masjid Indonesia (DMI). Diantara sekian banyak program yang harus dijalankan oleh setiap masjid yang masuk dalam organisasi DMI adalah, pengembangan pemahaman Al-Quran, melakukan dakwah, melakukan santunan, pengembangan keterampilan pemuda. Selain dari itu, DMI mengusulkan kepada pemerintah agar setiap perumahan, wilayah transmigrasi, taman hiburan dan lingkungan pendidikan dan kampus harus ada masjid di dalamnya. ${ }^{33}$

Keberadaan masjid di Indonesia hadir dengan intervensi relasional dengan pemerintah. Kesadaran pemerintah dalam memperhatikan masjid adalah bentuk kesadaran terhadap keberadaan umat Islam. Memperhatikan masjid sama sejajarnya dengan memperhatikan umat Islam itu sendiri. Kehadiran organisasi masjid yang lahir dari rahim politik dan pemerintah memang tidak akan lepas dari kepentingan pemerintah itu sendiri. Namun pada saat yang sama, masjid juga berpeluang untuk mempertemukan kepentingannya, sehingga kehadiran DMI itu harus betul-betul dijadikan titik temu mutualis.

Sebenarnya, sejarah panjang masjid dan kekuasaan juga bukan hal yang baru, mengingat hal serupa juga terjadi di lingkungan kekuasaan yang pernah ada dalam sejarah pertumbuhan Islam. Mulai dari masa Rasulullah, dinasti Umayyah hingga Ottoman Turki keberadaan masjid tidak pernah jauh dari lingkungan kekuasaan. Hanya saja hal yang perlu diperhatikan adalah negoisasi dua kepentingan antara keumatan (masjid sebagai tempat berkumpul umat Islam) dan kekuasaan itu sendiri.

\section{E. Ulama Dalam Ruang Demokrasi}

Kehadrian ulama di ruang politik adalah keniscayaan dalam kehidupan historis umat Islam dunia dan khususnya juga Indonesia. Begitu juga, simbol dan instrumen keagamaan seperti masjid juga menjadi gelanggang yang mempertemukan berbagai macam kepentingan, yaitu kepentingan elit politik, ulama dan kepentingan umat. Perjumpaan tersebut meniscayakan suatu produksi, terdapat produksi yang bersifat luas dan produksi dalam arti sempit. Produksi yang dimaksudkan dalam setiap perjumpaan elemen sosial adalah bangkitnya kesadaran setiap manusia terhadap apa yang mereka pahami tentang dunia dan bagaimana seharusnya dunia itu terbentuk. Bentuk produksi kesadaran yang bersifat luas berupa ide, landasan filososfis dan serangkaian format kebijakan yang bersifat mengikat (juridical form). Berikutnya, akan sampai pada produksi kesadaran yang lebih sempit, yaitu persoalan ekonomi yang secara konkret akan berbicara bagaimana kekayaan itu dibuat ${ }^{34}$.

Jadi kahadiran agama dengan sejumlah unsur yang melekat tidak selalu hanya menampilkan satu wajah pengabdian vertikal kepada Tuhan. Dalam ruang 2011),h. 59

32 John L. Esposito, Islam: The Straight Path (New York, NY: Oxford University Press, 2002),h. 84

${ }^{33}$ Donald J. Porter, Managing Politic and Islam in Indonesia (London: Routledge Curzon,

${ }^{34}$ Henri Lefebvre, The Production of Space, (UK: Basil Blackwell Ltd, 1991), h. $68-69$ 
sosial (social space), wajah agama adalah unsur sosial yang sangat bersifat duniawi, terlebih dalam kehadirannya di ruang politik. Menelisik pergumulan elit agama di ruang demokrasi dengan melibatkan masjid sebagai ruang perjumpaan juga terdapat proses produksi yang menarik untuk diurai. Konteks demokrasi di Kalimantan Barat dari data wawancara dan observasi dalam kajian terdapat produksi-produksi yang bersifat luas (filosofis) dan juga bersifat sempit konkret.

Terdapat sepuluh responden yang menjadi subyek dari kajian ini, dimana masing-masing responden adalah representasi dari elit agama yang berada di tiga lokasi di Kalimantan Barat, yaitu Kota Pontianak, Kubu Raya dan Singkawang. Dalam demokrasi di Kalimantan Barat yang menghadirkan dua pasangan kontetastan kuat calon gubernur non muslim yaitu Karolin Margaret (seorang Katolik) dan muslim yaitu Sutarmidji telah memunculkan beragam respon dari para ulama Kalimanatan Barat. Respon tersebut dalam diskursus keagamaan bersifat teologis. Diskursus teologis ini memunculkan keyakinan bahwa seorang Muslim wajib menjadi pemimpin serta menolak kepemimpinan non muslim atas muslim ${ }^{35}$.

Kewajiban muslim menjadi pemimpin tersebut dianggap berkaitan erat dengan keimanan, hanya saja hal tersebut tidak berbanding lurus dengan apa yang wajib dipilih oleh seorang muslim dalam kontestasi gubernur di Kalimantan Barat. Keberpihakan muslim menjadi tanggungjawab duniawi saja tidak membuat setiap muslim bertanggung jawab di akhirat. Memilih pemimpin dianggap tidak merubah keimanan seorang muslim kepada Allah, hanya jika memilih non muslim, maka urusan agama akan banyak diabaikan ${ }^{36}$.

Mengenai konsekuensi urusan agama terabikan tidak memiliki makna yang signifikan. Didalamnya tidak termuat indikator yang jelas mengenai urusan agama yang dimaksudkan. Ulama Kalimantan Barat hanya memiliki suatu pemahaman pandangan politik bahwa sistem politik dan persepsi tentang kehidupan dunia yang ideal itu adalah seperti apa yang dilakukan Nabi Muhammad dan Khulafaur Rasyidin dalam konteks politik ${ }^{37}$.

Selain dari bentuk politik ideal yang hanya menyebut dua masa tersebut, maka kemudian juga berdampak pada keterbatasan dalam menentukan figur pemimpin yang ideal. Para elit agama di Kalimantan Barat cukup normatif saja, hanya pada sifat yang menjadi landasan, bukan pada identitas dari figur ideal seorang pemimpin. Ulama Kalimantan Barat menerima siapapun yang maju tampil berkompetisi sebagai calon gubernur tanpa menentukan identitas dan latar belakang dari calon tersebut. Di sisi yang lain, ulama Kalimantan Barat juga meyakini tentang surah Al-Maidah surah 51 tentang kepemimpinan untuk tidak memilih pemimpin non muslim, tetapi itu tidak menjadikan ulama Kalimantan Barat menolak kehadiran calon gubernur dari kalangan non muslim ${ }^{38}$.

35 Data wawancara dari 5 responden yang menyatakan seorang muslim wajib menjadi pemimpin dan menolak kepemimpinan non muslim terhadap muslim. Diantara responden tersebut adalah, Hamid dari Kubu Raya diwawancarai hari Senin 5 Maret 2018

36 Persoalan kebebasan memilih diberikan seluas-luasnya kepada kebebasan individu, karena persoalan pilihan tidak dapat merubah status keimanan seseorang. Persepsi disampaikan oleh seluruh responden yang berjumlah 10 orang

${ }^{37}$ Konsepsi tentang wawasan politik Nabi Muhammad dan Khulafaur Rosyidin diuangkap oleh enam responden dengan kreteria yang juga kurang jelas. Sehingga peneliti berasumsi bahwa ulama Kalimantan Barat tidak memiliki wawasan yang luas mengenai persoalan politik. Wawancara dilakukan di Bulan Maret 2018.

${ }^{38}$ Ahmad Yusuf, salah satu ustadz di Kota Pontianak diwawancarai Hari Sabtu tanggal 24 Maret 2018. 
Berangkat dari sejumlah respon di atas, sebagai konsekuensi fungsional dari ulama sebagai pialang budaya, ulama Kalimantan Barat membuat konsepsi politik dalam rangka menggiring pilihan politik (political preference) masyarakat Kalimantan Barat dalam pemilihan gubernur tahun 2018 sangat normatif. Pesan mereka berupa ajakan untuk memilih mereka yang jujur, adil dan taat beragama. Sementara pesan ajakan politik identitas atas nama agama di beberapa masjid ada, tetapi hanya disampaikan dalam penyampaian yang wajar sebatas pengetahuan saja $^{39}$.

Data di atas menunjukkan bahwa agama yang didalamnya ada simbol agama sepert ulama dan masjid adalah fenomena sosial yang merefleksikan ekspresi sosial sekaligus juga menunjukkan alam pikir kolektif. Dalam ekspresi tersebut tidak hanya alam pikir kolektif yang luas tetapi juga meminta keniscayaan yang terukur, karena agama sebenarnya adalah perantara antara manusia kepada apa yang mereka butuhkan ${ }^{40}$. Dari perspektif sosial dapat dikategorikan bahwa pergumulan ulama di ruang demokrasi di Kalimantan Barat memunculkan diskursus alam pikir kolektif (filosofis) dan kecenderungan konkret atau sempit. Kategori pertama berupa kesadaran bahwa seorang muslim adalah pemimpin, sementara tujuan yang terukur dari landasan tersebut adalah terpenuhinya urusan kebutuhan beragama. Sebenarnya ukuran ini masih terlalu luas, sehingga masih sangat susah untuk dibuat ukuran yang jelas. Untuk sementara penyebutan urusan kebutuhan beragama minimal menjadi penanda ukur, walau perlu didefinisikan lebih lanjut.

Pandangan teologis ulama Kalimantan Barat dan relasinya dengan al-Islam wa Daulah jika merujuk pada perdebatan teoritis antara Islamism dan scularism atau simbolik dan substantif tidak berada pada dua sisi ekstrem tersebut, tetapi cukup merasa nyaman dengan atmosfer demokrasi demokrasi yang sudah berjalan saat ini. Begitu juga dengan kawasan kekuasaan, ulama Kalimantan Barat khususnya di Pontianak, Kubu Raya dan Singkawang berada di lajur yang netral, hal tersebut terlihat dari data hasil wawancara dan data observasi yang tidak merepresentasikan dari calon pasangan gubernur tertentu

\section{F. Kesimpulan Dan Saran}

Secara ringkas, pergumulan ulama dan politik berangkat dari rumusan masalah pada kajian ini dapat dijelaskan beberapa sebagai berikut

1. Diskursus yang dikembangkan oleh ulama Kalimantan Barat dalam ruang demokrasi berupa propaganda teologis-doktriner yang mewajibkan umat Islam untuk mengambil kesempatan menjadi seorang pemimpin .

2. Bntuk ideal pemimpin ada pada landasan sifat yang melekat pada setiap calon pemimpin.

${ }^{39}$ Terpantau di Masjid Raya Mujahidin Kota Pontianak dan Kubu Raya pada bulan Maret 2018 dan Jawban enam reponde dari 10 responde yang diwawanca, Maret 2018.

${ }^{40}$ Emile Durkheim, Elementary Formof Religious Life ,(London: Gorge Allen Unwin Ltd, 1956) h.10-11 
3. Konsepsi dasar untuk mobilisasi kecenderungan pilihan politik masyarakat yang digunakan ulama Kalimantan Barat bersifat universal seperti kejujuran, keadilan dan ketaatan beragama.

Dengan demikian, Ulama Kalimantan Barat dalam ruang demokrasi dan sistem kenegaraan yang terdikotomi menjadi Islamis dan sekuler dapat dikatakan berada pada posisi moderat. Sehingga secara implisit dapat dikatakan bahwa Kalimantan Barat masih cukup aman dari paham-paham yang merusak kesatuan berbangsa dan bernegara.

Di sisi yang lain tentu hal di atas tidak berarti tidak ada persoalan. Persoalan pokok Ulama Kalimantan Barat belum memiliki gagasan konkret dan terukur. Sampai saat ini baru hanya ada dorongan filosofis bagi setiap muslim untuk menjadi pemimpin, tetapi belum memiliki tujuan yang betul-betul terukur, sehingga sangat sulit untuk menerjemahkan dalam bentuk agenda kebijakan politik.

\section{Daftar Pustaka}

Abrahamian, Ervan, Khomeinism Essays on The Islamic Republic, Berkeley: Universitas of California Press, 1993

Amstrong, Karen, Muhammad Prophet for Our Time, New York : Harper Collins, 2007

Arifin, Achmad Zainal, Charisma and Rasionalisation in Modernising Pesantren: Changing Values in Traditional Islamic Education in Java, Sydney : The University of Western Sydney, 2013

Arikunto, Suharsimi, Prosedur Penelitian Suatu Pendekatan Praktek, Jakarta: Rieneka Cipta, 1991

Al-Mawardi, Al-Ahkamus Sulthoniyah wal Wilayatud Diniyah, Darul Fikr, Beirut, Cetakan 1,1960

Ayubi, Nazih N, Political Islam: Relegion and Politic in The Arab World, New York :Taylor and E Library 1991

Azwar, Saifuddin, Metode Penelitian, Yogyakarta: Pustaka Pelajar, 2005

Basyar, M Hamdan, "Dinamika Peran Ularna dalam Perpolitikan Nasional Pasca Orde Baru", Jurnal Penelitian Politik, http://ejournal.politik.lipi.go.id/index.php/jpp/article/view/504/313, Diakses, 31 Oktober 2017

Bolland, B.J., The Struggle of Islam in Modern Indonesia ,London: Springer, 1982

Burhanudin, Jajat, Ualama dan Kekuasaan, Pergumulan Elit Muslim dalam Sejarah Indonesia, Jakarta: Mizan, 2012.

Cox, Harvey, The Secular City; Secularization and Urbanization in Theological Perspective, New York: The Macmillan Company, 1965

Durkheim, Emile, Elementary Formof Religious Life, London: Gorge Allen Unwin Ltd, 1956

Esposito John L., Islam: The Straight Path ,New York, NY: Oxford University Press, 2011

Geertz, Clifford, The Religion of Java, Chicago and London: The University of Chicago Press, 1960

Hasan, Iqbal, Metodologi Penelitian dan Aplikasinya, Jakarta:Ghalia Indonesia,2002 
Lefebvre, Henri, The Production of Space, UK: Basil Blackwell Ltd, 1991

Humpreys, Stephen, Islamic History: A Frame Work for Inquiry, London: I.B. Thauris, 1999

IPAC Report, After Ahok: The Islamist Agenda in Indonesia, Institute For Policy Analysis of Conflict IPAC, 6 April 2018

Karisipahi, Sena, The Middle Est Journal, Vol. 63, No. 1. 2009.

Kiddie, Nikki R., Studia Islamica, No. 29, 1969.

Isma'il bin katsir, Tafsir Ibnu Katsir, Maktabah al-Syamilah

Lewis, Bernard, Islam Liberalisme Demokrasi: membangun sinergi warisan sejarah, doktrin dan konteks global, Jakarta : Paramadina, 2002

Lee, Robert D. "Religion and Politic in Iran, New York: Westview Press, 2014

Mandaville, Peter, Global Politic Islam, New York : Taylor and E-Library, 2007

Mardalis, Metode Penelitian: Suatu Pendekatan Proposal, Jakarta: Bumi Aksara, 1995

Miller, Elmer S. and Charles A. Weitz, Introduction to Anthropology, Eaglewood Cliffs:

Moleong, Lexi J, , Metodelogi Penelitian Kualitatif,, Bandung: PT. Remaja Rosda Karya, 2002

Mudzhar, M. Atho, Fatwa of the Council of Indonesian Ulama: A Study of Islamic Legal

Nofiaturrahmah, Fifi, "Melacak Peran Kyai-Santri dalam Politik Kebangsaan di Indonesia", JURNAL ISLAMIC REVIEW, journal.ipmafa.ac.id/index.php/jie/article/download/26/pdf (diakses, 31 Oktober 2018

Oktara, Arie, "Politik Tuan Guru di Nusa Tenggara Barat", Government: Jurnal Ilmu Pemerintahan Volume 8, Nomor 2, Juli 2015

Owen, John M., Confronting Political Islam, New Jersey: Princeton University Press, 2015

Peters, Francis E., Muhammed and the Origins of Islam ,Albany, NY: State University of New

Porter, Donald J., Managing Politic and Islam in Indonesia, London: Routledge Curzon, 2002

Sibai , Mohamed Makki, Mosque Libraries New York, NY: Mansell Publishing Limited, 1987

Sukmadinata, Nana Syaodih, Metode Penelitian Pendidikan, Bandung: PT. Remaja Rosdakarya, 2007

Thought in Indonesia 1975-1988, Jakarta: INIS, 1993.

Tibi, Bassam, Islam Between Culture and Politics, New York: Palgrave Macmilan, 2001

Weber, Max, Theory of Social and Economic Organization, Glancoe-III: The Free Press, 1957

Internet

"Resolusi Jihad NU Dan Perang Empat Hari Di Surabaya | NU Online," accessed January 10, 2017, http://www.nu.or.id/post/read/72250/resolusi-jihad-nudan-perang-empat-hari-di-surabaya-

https://surface.syr.edu/honors_capstone 
| Abdul Mukti

https://www.facebook.com/notes/wira-saputra/pemimpin-yang-baik-menurutpandangan-islam-disertai-dalil/10152986232814392/ 